\title{
PHYSIOLOGICAL QUALITY EVALUATION OF THE RADII Schinus terebinthifolius SEEDS ${ }^{1}$
}

\author{
MAURO VASCONCELOS PACHECO ${ }^{2}$, CLARISSA SANTOS DA SILVA ${ }^{3}$, TIAGO MADRUGA TELESCA SILVEIRA4, \\ LETÍCIA DOS SANTOS HÖLBIG ${ }^{5}$, FÁBIO SCHAUN HARTER ${ }^{5}$, FRANCISCO AMARAL VILLELA ${ }^{6}$
}

\begin{abstract}
Schinus terebinthifolius is a native forest species which may be used in recuperating degraded areas and in urban afforestation. In order to evaluate the efficiency of methods for separating lots of S. terebinthifolius seeds into vigor levels, five lots of seeds were qualitatively evaluated for their moisture content, germination, first count, accelerated aging (the traditional and the saturated salt methods), germination speed index, average time of germination and seedling length and dry weight. The results showed that the tests of first germination count, accelerated aging at $41{ }^{\circ} \mathrm{C}$ for 72 hours, average time of germination, seedling length and dry matter permitted the separation of $S$. terebinthifolius seeds into different vigor levels.
\end{abstract}

Index terms: forest species, germination, physiological potential.

\section{AVALIAÇÃO DA QUALIDADE FISIOLÓGICA DE SEMENTES DE Schinus terebinthifolius RADII}

\begin{abstract}
RESUMO - Schinus terebinthifolius Raddi é uma espécie florestal nativa que pode ser utilizada na recomposição de áreas degradadas e na arborização urbana. Para avaliar a eficiência de métodos que possibilitem separar lotes de sementes de aroeira-vermelha em níveis de vigor, foram utilizados cinco lotes de sementes avaliados qualitativamente pela determinação do teor de água, germinação, primeira contagem da germinação, envelhecimento acelerado (procedimento tradicional e o método alternativo com o uso de solução saturada de $\mathrm{NaCl}$ ), índice de velocidade de germinação, tempo médio de germinação, comprimento e massa seca de plântulas. Os testes de primeira contagem da germinação, envelhecimento acelerado a $41^{\circ} \mathrm{C}$ por $72 \mathrm{~h}$, tempo médio de germinação, comprimento de plântulas e matéria seca de plântulas permitem a separação dos lotes de sementes de $S$. terebinthifolius em níveis de vigor.
\end{abstract}

Termos para indexação: espécie florestal, germinação, potencial fisiológico.

${ }^{1}$ Submitted on 18/02/10. Accepted for publication on 16/03/11.

${ }^{2}$ Dr. Adjunct Prof. I of the Agricutlural Science Unit of the Federal University of Rio Grande do Norte (UAECIA/UFRN), pachecomv@ ufrnet.br

${ }^{3}$ Prof. Dr. of the University of the Campanha Region (INTEC/URCAMP) clarissas_s@hotmail.com
${ }^{4} \mathrm{MSc}$. in Agronomy. tiagro@hotmail.com

${ }^{5}$ Doctoral student in Seed Science and Technology of the Federal University of Pelotas (FAEM/UFPel) 1sholbig@yahoo.com.br, fabiosharter@yahoo.com.br

${ }^{6}$ Dr. Associate Prof. II of the Federal University of Pelotas ( FAEM/ UFPel) francisco.villela@ufpel.edu.br 


\section{INTRODUCTION}

Popularly known as Brazilian pepper, Schinus terebinthifolius Raddi is a forest species belonging to the Anacardiaceae, found growing from the states of Pernambuco to Rio Grande do Sul. It is a pioneer species with a rapid field development (Lorenzi, 1998) and is recommended in the recuperation of degraded areas, e.g., those used for the extraction of sand (Souza et al., 2001) and bauxite (José et al., 2005). This species also has antibacterial properties (Guerra et al., 2000; Amorim and Santos, 2003). The ornamental tree, measuring between $5-10 \mathrm{~m}$ in height, produces flowers, which are visited by bees to collect nectar and pollen and the wood can be used for building, firewood and making charcoal (Lorenzi, 1998).

Forest species seeds show great physiological heterogeneity since several factors, including habitat, collection period, storage conditions and water content, directly affect the vigor.

Seed vigor is defined as a sum of properties that determines the physiological potential for a rapid and uniform emergence, with the development of normal seedlings under an ample range of environmental conditions (AOSA, 1983).

The germination test is normally used to evaluate germination but is done under favorable conditions, and consequently, this test by itself cannot detect important differences between seed vigors (Bewley and Black, 1994). Included among the vigor tests are those related to the speed of development, such as the first germination count (Nakagawa, 1994; Piña-Rodrigues et al., 2004), and germination speed index (Maguire, 1962).

The analysis of seedling growth provides additional data that complement the germination test, allowing diverse degrees of vigor to be distinguished. More vigorous seeds would result in seedlings of greater length and weight (AOSA, 1983; Piña-Rodrigues et al., 2004).

Tests of resistance, such as accelerated aging, simulate stressful conditions for the seed (temperature and high relative humidity), causing a high respiratory rate and the consumption of nutrient reserves, which in turn accelerate metabolic deterioration processes (Marcos Filho, 1994).

This study aimed to compare different methods of evaluating the physiological quality of batches of $S$. terebinthifolius seeds in order to establish the most effective tests for distinguishing differences in vigor levels between different seed lots.

\section{MATERIAL AND METHODS}

This study was carried out at the Seeds Didactic Laboratory, in the Eliseu Maciel Agronomy Faculty, Federal University of Pelotas. Five seed lots collected from the municipalities of Pelotas and Capão do Leão, in Rio Grande do Sul State, were used. The fruits were first submitted to brief friction between two pieces of sandpaper $\left(n^{\circ} 50\right)$ to remove the papyraceous exocarp and facilitate germination.

The following parameters were evaluated for each seed lot: moisture content - performed in an oven at 105 $\pm 3{ }^{\circ} \mathrm{C} / 24 \mathrm{~h}$, using two subsamples of about $4 \mathrm{~g}$ for each lot (Brasil, 1992); germination - four replicates of 50 seeds, kept wrapped in paper towels and moistened in distilled water at a ratio of 2.5 times the dry weight of the paper. They were kept in a Biochemical Oxygen Demand (B.O.D.) germinator at a constant temperature of $20{ }^{\circ} \mathrm{C}$ (Medeiros and Zanon, 1998a) for 13 days; first germination countobtained by counting the number of germinated seeds at 7 days after sowing, quantified during the germination test; germination speed index (GSI) - conducted during the germination test according to Maguire (1962), as the sum of the ratio between the daily number of germinated seeds and the day of evaluation: $\mathrm{IVG}=\mathrm{G} 1 / \mathrm{N} 1+\mathrm{G} 2 / \mathrm{N} 2+\mathrm{G} 3 /$ $\mathrm{N} 3+\ldots+\mathrm{Gn} / \mathrm{Nn}$, where $\mathrm{G} 1, \mathrm{G} 2, \mathrm{G} 3, \ldots, \mathrm{Gn}=$ number of germinated seeds on the day of observation, and N1, $\mathrm{N} 2, \mathrm{~N} 3, \ldots, \mathrm{Nn}=$ the number of days after sowing.; mean germination time (MGT) - conducted during the germination test according to Silva and Nakagawa (1995), in which the results appear in the days following sowing; seedling length - normal seedlings from each repetition were measured and results expressed as $\mathrm{mm} /$ seedling; seedling dry matter - normal seedlings from each repetition were packed in paper bags and kept in an oven with forced ventilation, set at $80^{\circ} \mathrm{C}$ for 24 hours. The seedlings were weighed with a precision of $0.001 \mathrm{~g}$, and the results expressed in $\mathrm{mg} /$ seedling (Nakagawa, 1999); accelerated aging (traditional procedure) - a sufficient quantity of seeds was distributed over an aluminum screen, which was fixed inside each plastic gerbox, forming an individual compartment (mini-camera). Forty $\mathrm{mL}$ of distilled water were added to each mini-camera, which was transferred to a B.O.D. germinator at $41{ }^{\circ} \mathrm{C}$ for 24 , 48 and 72 hours. After each period, four repetitions of 50 seeds were submitted to the germination test, calculating the percentage of normal seedlings obtained 7 days after sowing; accelerated aging (saturated solution of $\mathrm{NaCl}$ ) 
- similar to the traditional procedure, but adding $40 \mathrm{~mL}$ of a saturated solution of sodium chloride ( $40 \mathrm{~g}$ of salt in each $100 \mathrm{~mL}$ of distilled water), instead of water, in the bottom of each plastic box, thereby establishing an environment with 76\% RH (Jianhua and McDonald, 1996).

The experimental design was completely random, with four replicates and a statistical analysis was made by comparing means using Tukey's test at 5\% probability. The values expressed in percentages were transformed into $\operatorname{arc} \operatorname{sen} \sqrt{x} / 100$ and the data analyzed using the statistical program ESTAT (Kronka and Banzato, 1995).

\section{RESULTS AND DISCUSSION}

The results for the moisture content, germination and vigor tests of Schinus terebinthifolius seeds are shown in Table 1. The moisture content of seeds ranged between 11.9 and $13.6 \%$, but the lot with a low content did not differ statistically from those with higher water contents for the seed quality parameters evaluated.

TABLE 1. Average values of moisture content (MC), germination (G), first germination count (FGC), germination speed index (GSI), mean germination time (MGT), seedling length (SL) and seedling dry matter (SDM), for five lots of Schinus terebinthifolius Raddi seeds.

\begin{tabular}{|c|c|c|c|c|c|c|c|}
\hline & $\mathrm{MC}$ & $\mathrm{G}$ & FGC & \multirow[t]{2}{*}{ GSI } & \multirow{2}{*}{$\begin{array}{l}\text { MGT } \\
\text { (days) }\end{array}$} & \multirow{2}{*}{$\begin{array}{c}\text { SL } \\
(\mathrm{cm})\end{array}$} & \multirow{2}{*}{$\begin{array}{l}\text { SDM } \\
(\mathrm{mg})\end{array}$} \\
\hline & & $\%$ & & & & & \\
\hline 1 & 12,7 & $74 \mathrm{a}$ & $48 \mathrm{a}$ & $4,63 \mathrm{a}$ & $8,2 \mathrm{~b}$ & $7,4 \mathrm{a}$ & $3,3 \mathrm{ab}$ \\
\hline 2 & 11,9 & $57 \mathrm{ab}$ & $28 \mathrm{bc}$ & $3,38 \mathrm{a}$ & $8,6 \mathrm{~b}$ & $6,9 \mathrm{~b}$ & $3,7 \mathrm{a}$ \\
\hline 3 & 12,4 & $77 \mathrm{a}$ & $22 \mathrm{c}$ & $4,13 \mathrm{a}$ & $9,6 \mathrm{a}$ & $6,2 \mathrm{c}$ & $2,3 \mathrm{c}$ \\
\hline 4 & 11,9 & $38 \mathrm{~b}$ & $12 \mathrm{~d}$ & $2,50 \mathrm{~b}$ & 9,6 a & $6,5 \mathrm{bc}$ & $3,4 \mathrm{ab}$ \\
\hline 5 & 13,2 & $55 \mathrm{ab}$ & $36 a b$ & $3,50 \mathrm{a}$ & $8,2 \mathrm{~b}$ & $6,8 \mathrm{~b}$ & $2,9 \mathrm{bc}$ \\
\hline $\mathrm{VC}(\%)$ & & 16,2 & 15,2 & 19,3 & 3,8 & 2,9 & 8,8 \\
\hline
\end{tabular}

Average followed of same letter (in the column) does not differ by the Tukey test at $5 \%$ probability.

The results of the germination test (Table 1) only showed a significant difference for lot 4 , classified as having a low vigor, compared to higher values for lots 1 and 3. In pumpkin seeds, Barros et al., (2002) distinguished different levels of physiological quality for the lots, proving that the germination test is a good indicator of physiological seed quality. However, Bhering et al. (2000) concluded that even when the germination test is a good indicator of seed quality, it did not guarantee high field emergence in cucumber seed lots. This agrees with the results obtained in this study, where although the germination test distinguished between low and high vigor lots, there was no agreement with some vigor tests.

Lot 3, which showed a high value for the germination test, was among the worst lots for first count, seedling dry matter and seedling length. Since the germination test is done under favorable conditions, it does not really predict vigor, and consequently, the seed performance under adverse field conditions (França Neto et al., 1988).
The first count test efficiently separated the lots regarding their physiological quality. The seeds from lot 1 showed higher values for the first count, and lots 2 and 5 were classified with an intermediate physiological quality, whereas lots 3 and 4 showed the worst performance. Lot $3 \mathrm{had}$ a poor performance for this test compared to the germination test, indicating that vigor tests are needed to better separate lots. This test efficiently separated lots of Calendula officinalis L. (Silveira et al., 2002) and Vigna unguiculata L.Walp (Torres and Bringel, 2005) seeds regarding vigor levels.

The germination speed index (GSI) (Table 1), only classified the $4^{\text {th }}$ lot with an inferior quality since a reduction in germination speed is not the first step in the seed deterioration process . Nakagawa (1999) commented that the first count test often shows the germination speed between lots better than the actual germination speed index test itself and this was observed in the present study, where the GSI showed a lower sensibility for distinguishing vigor levels between seed 
lots and detected only the lots with low and high vigor.

The mean germination time (Table 1), as well as the seedling length and seedling dry matter, highlighted the inferiority of lot 3 as observed from the first count test. The lowest mean germination times were observed in lots 1, 2 and 5, characterizing them as more vigorous, while the highest values for the less vigorous seeds, were observed in lots 3 and 4. In Tibouchina pulchra Cogn and T. sellowiana Cogn, there was a tendency for the mean seed germination time to decrease with an increase in germination speed (Freitas, 1998).

The superiority of lot 1 and the inferiority of lot 3 were also observed in the results for seedling length, dry matter, mean germination time and first count, indicating a good relationship between them. However, lots 2, 4 and 5 showed differences for these parameters.

Only differences for the higher and lower means were observed for both accelerated aging test methods and periods, except for the accelerated aging test (traditional procedure) conducted for 72 hours, which separated the lots better, classifying them into high, intermediate and low physiological quality.

Although the results from the accelerated aging test with $\mathrm{NaCl}$ and the traditional test at 24 and $48 \mathrm{~h}$ agree with the other tests for lot 4, they did not show that lot 3 had the worst vigor, indicating that these are unsuitable parameters for separating lots according to their level of physiological quality.

In the accelerated aging test (traditional procedure) at $72 \mathrm{~h}$, lot 1 was identified as having the highest physiological potential, lots 2 and 5 as having an intermediate physiological quality and lots 3 and 4 as having a poor physiological quality (Table 2). These results were supported by those from the other tests.

TABLE 2. Results (\%) of accelerated aging test (AA), using traditional and saturated solution of NaCl methods, (G) germination (FGC) first germination count in five lots of Schinus terebinthifolius Raddi seeds.

\begin{tabular}{|c|c|c|c|c|c|c|c|c|}
\hline \multirow{2}{*}{ LOT } & \multirow[t]{2}{*}{$\mathrm{G}$} & \multirow[t]{2}{*}{ FGC } & \multicolumn{3}{|c|}{ AA (traditional) } & \multicolumn{3}{|c|}{$\mathrm{AA}(\mathrm{NaCl})$} \\
\hline & & & $24 \mathrm{~h}$ & $48 \mathrm{~h}$ & $72 \mathrm{~h}$ & $24 \mathrm{~h}$ & $48 \mathrm{~h}$ & $72 \mathrm{~h}$ \\
\hline & \multicolumn{8}{|c|}{ } \\
\hline 1 & $74 \mathrm{a}$ & $48 \mathrm{a}$ & $38 \mathrm{a}$ & $46 \mathrm{a}$ & $32 \mathrm{a}$ & $42 \mathrm{a}$ & $47 \mathrm{a}$ & $39 \mathrm{a}$ \\
\hline 2 & $57 \mathrm{ab}$ & $28 \mathrm{bc}$ & $29 \mathrm{a}$ & $36 \mathrm{ab}$ & $27 \mathrm{ab}$ & $30 a$ & $37 \mathrm{a}$ & $25 \mathrm{ab}$ \\
\hline 3 & 77 a & $22 \mathrm{c}$ & $29 a$ & $40 \mathrm{ab}$ & $11 \mathrm{c}$ & $39 a$ & $48 \mathrm{a}$ & $39 a$ \\
\hline 4 & $38 \mathrm{~b}$ & $12 \mathrm{~d}$ & $11 \mathrm{~b}$ & $14 \mathrm{c}$ & $9 \mathrm{c}$ & $12 \mathrm{~b}$ & $8 \mathrm{~b}$ & $12 \mathrm{~b}$ \\
\hline 5 & $55 \mathrm{ab}$ & $36 \mathrm{ab}$ & $40 \mathrm{a}$ & $31 \mathrm{~b}$ & $22 \mathrm{~b}$ & $33 a$ & $34 \mathrm{a}$ & $28 \mathrm{a}$ \\
\hline $\mathrm{VC}(\%)$ & 16,2 & 15,2 & 10,6 & 11 & 16,1 & 10,8 & 12,2 & 15,5 \\
\hline
\end{tabular}

Average followed of same letter (in the column) does not differ by the Tukey test at $5 \%$ probability.

It was observed that during the $48 \mathrm{~h}$ period of aging, in both the traditional and saline solution methods, there was a trend of increasing percentage germination. The 48 $\mathrm{h}$ period may have induced seeds to pre-soak, resulting in higher values compared to the $24 \mathrm{~h}$ period.

The $S$. terebinthifolius seeds subjected to accelerated aging showed a reduction in physiological quality with an increase in the exposure period, probably due to the damage caused in cell membrane permeability. The changes in metabolism, solutes and water exchange between cells and the external environment are degenerative changes that determine loss of seed viability (Vieira and Carvalho 1994). Similar results were obtained with Caesalpinia peltophoroides Benth. (Pontes et al., 2006) and Chorisia speciosa St. Hil. seeds (Fanti and Perez, 2005).

It may be concluded that the traditional method of accelerated aging $(100 \% \mathrm{RH})$ for $72 \mathrm{~h}$, gave better results for separating lots of $S$. terebinthifolius seeds according to their physiological quality. There is a consistent trend for all the tests classifying seed vigor levels, especially for first germination count, average germination time, seedling length and seedling dry matter tests, where lot 3 was classified as having the worse quality, followed by lot 4.

The data show that not all the parameters used were efficient in separating the lots of $S$. terebinthifolius seeds 
for physiological potential. However, by comparing the means obtained for the germination and vigor tests, it was possible to classify the lots into three vigor levels.

In general, the tests showed that lot 1 seeds possessed the best physiological quality. The results for seeds from lots 2 and 5 varied depending on the physiological test employed: sometimes seeds were classified as having a high or intermediate physiological quality level. In the majority of vigor tests, the results allowed lots 3 and 4 to be classified as less vigorous.

\section{CONCLUSION}

First germination count, traditional accelerated aging at $72 \mathrm{~h} / 41{ }^{\circ} \mathrm{C}$, mean germination time, seedling length and dry matter tests were efficient to rank S. terebinthifolius seed lots into different vigor levels.

\section{REFERENCES}

AMORIM, M.M.R.; SANTOS, L.C. Tratamento da vaginose bacteriana com gel vaginal de aroeira (Schinus terebinthifolius Raddi): ensaio clínico randomizado. Revista Brasileira de Ginecologia e Obstetrícia, v.2, p.95-102, 2003.

ASSOCIATION OF OFFICIAL SEED ANALYSTS. Seed vigour testing handbook. East Lasing, 1983. 93p. (To the Handbook on Seed Testing. Contribution, 32).

BARROS, D.I. DIAS, D.C.F.S.; BHERING, M.C.; DIAS, L.A.S.; PUIATTI, M. Avaliação do vigor de sementes de abobrinha (Curcubita pepo) pelo teste de tetrazólio. Horticultura Brasileira, v.20, n.2, p.1-5, 2002.

BEWLEY, J.D.; BLACK, M. Seeds: physiology of development and germination. New York: Plenum Press, 1994. 445p.

BHERING, M.C.; DIAS, D.C.F.S.; GOMES, J.M.; BARROS, D.I. Métodos para avaliação do vigor de sementes de pepino. Revista Brasileira de Sementes, v.22, n.2, p.171-175, 2000.

BRASIL. Ministério da Agricultura e Reforma Agrária. Secretaria NacionaldeDefesa Agropecuária. Departamento Nacional de Produção Vegetal. Coordenação de Laboratório Vegetal. Regras para análise de sementes. Brasília, DF, 1992. 365p.

FANTI, S.C.; PEREZ, S.C.J.G.A. Efeitos do envelhecimento precoce no vigor de sementes de Chorisia speciosa St. Hil. - Bombacaceae. Revista Árvore, v.3, p.345-352, 2005.

FRANÇA-NETO, J.B.; J.B.; PEREIRA, L.A.G.; COSTA, N.P.; KRYZANOWSKY, F.C.; HENNING, A.A. Metodologia do teste de tetrazólio em semente de soja. Londrina: Embrapa - CNPSO, 1988. 58p. (EMBRAPA CNPSO. Documentos, 32).

FREITAS, N.P. Análise do efeito da luz na germinação de sementes de Tibouchina pulchra Cogn. e Tibouchina sellowiana Cogn. (Melastomataceae). Rio Claro: UNESP, 1998. 88f. Tese (Doutorado em Ciências Biológicas) - Universidade Estadual Paulista, 1998.

GUERRA, M.J.M.; BARREIRO, L.M.; RODRÍGUEZ, M.Z.; RUBALCABA, Y. Actividad antimicrobiana de um extracto fluido at $80 \%$ de Schinus terebinthifolius Raddi (Copal). Revista Cubana Plantas Medicinales, v.1, p.23-25, 2000.

JIANHUA, Z.; McDONALD, M.D. The saturated salt accelerated aging test for small-seeded crops. Seed Science and Technology, v.1, p.23-131, 1996.

JOSÉ, C.A.; DAVIDE, A.C.; OLIVEIRA, S.L. Produção de mudas de aroeira (Schinus terebinthifolius Raddi) para recuperação de áreas degradadas pela mineração de bauxita. Cerne, v.11, n.2, p.187-196, 2005.

KRONKA, S.N.; BANZATTO, D.A. ESTAT: sistema para análise estatística versão 2.0. Jaboticabal: FUNEP, 1995. 247p.

LORENZI, H. Árvores brasileiras: manual de identificação e cultivo de plantas arbóreas nativas do Brasil. 2.ed. Nova Odessa: Editora Plantarum, 1998. $352 p$.

MAGUIRE, J.D. Speed of germination-aid in selection and evaluation for seedlings emergence and vigor. Crop Science, v.1, p.176-177, 1962.

MARCOS FILHO, J. Teste de envelhecimento acelerado. In: VIEIRA, R.D.; CARVALHO, N.M. (Ed.). Testes de vigor em sementes. Jaboticabal: FUNEP, 1994. p.133150.

MEDEIROS,A.C.S.;ZANON,A.Substratosetemperaturas para teste de germinação de sementes de aroeira-vermelha (Schinus terebinthifolius Raddi). Comunicado TécnicoEMBRAPA FLORESTAS, Colombo, v.1, n.32, p.1-3, 1998.

NAKAGAWA, J. Testes de vigor baseados na avaliação das plântulas. In: VIEIRA, R.D.; CARVALHO, N.M. (Ed.). Testes de vigor em sementes. Jaboticabal: FUNEP, 1994. p.49-85. 
NAKAGAWA, J. Testes de vigor baseados no desempenho das plântulas. In: KRZYZANOWSKI, F.C.; VIEIRA, R.D.; FRANÇA NETO, J.B. (Ed.). Vigor de sementes: conceitos e testes. Londrina: ABRATES, 1999. p.2.12.24 .

PIÑA-RODRIGUES， F.C.M.; FIGLIOLIA， M.B.; PEIXOTO, M.C. Testes de qualidade. In: FERREIRA, A.G.; BORGHETTI, F. (Ed.). Germinação: do básico ao aplicado. Porto Alegre: Artmed, 2004. p.283-297.

PONTES, C.A.; CORTE, V.B.; BORGES, E.E.L.; SILVA, A.G.; BORGES, R.C.G. Influência da temperatura de armazenamento na qualidade das sementes de Caesalpinia peltophoroides Benth. (sibipiruna). Revista Árvore, v.30, n.1, p.43-48, 2006.
SILVEIRA, M.A.M.; VILLELA, F.A.; TILLMANN, M.A.A. Comparação de métodos para avaliação da qualidade fisiológica em sementes de calêndula. Revista Brasileira de Sementes, v.2, p.24-30, 2002.

SOUZA, P.A.; VENTURIN, N.; MACEDO, R.L.G.; ALVARENGA, M.I.N.; SILVA, V.F. Estabelecimento de espécies arbóreas em recuperação de área degradada pela extração de areia. Cerne, v.2, p.43-52, 2001.

TORRES, S.B.; BRINGEL, J.M.M. Avaliação da qualidade sanitária e fisiológica de sementes defeijãomacassar. Caatinga, v.18, n.2, p.88-92, 2005.

VIEIRA, R.D.; CARVALHO, N.M. Testes de vigor em sementes. Jaboticabal: FUNEP, 1994. 164p. 